\title{
Spatiotemporal segregation of ocean sunfish species (Molidae) in the eastern North Pacific
}

\author{
M. C. Arostegui ${ }^{1, *}$, C. D. Braun ${ }^{2,4}$, P. A. Woodworth-Jefcoats ${ }^{3}$, D. R. Kobayashi ${ }^{3}$, \\ P. Gaube ${ }^{1}$ \\ ${ }^{1}$ Air-Sea Interaction and Remote Sensing Department - Applied Physics Laboratory, University of Washington, Seattle, \\ WA 98105, USA \\ ${ }^{2}$ School of Aquatic and Fishery Sciences, University of Washington, Seattle, WA 98105, USA \\ ${ }^{3}$ National Oceanic and Atmospheric Administration (NOAA) Pacific Islands Fisheries Science Center (PIFSC), Honolulu, \\ HI 96818, USA \\ ${ }^{4}$ Present address: Biology Department, Woods Hole Oceanographic Institution, Woods Hole, MA 02543, USA
}

\begin{abstract}
Ocean sunfishes or molas (Molidae) are difficult to study as a result of their extensive movements and low densities in remote waters. In particular, little is known of the environmental niche separation and differences in the reproductive or movement ecology of molids in sympatry. We investigated spatiotemporal dynamics in the distribution of the common mola Mola mola, sharptail mola Masturus lanceolatus, and slender mola Ranzania laevis in the eastern North Pacific. We used observer data from a commercial fishery consisting of $85000+$ longline sets spanning $24 \mathrm{yr}$, $>50^{\circ}$ in longitude, and $>45^{\circ}$ in latitude. Satellite altimetry analysis, species distribution modeling, and multivariate ordination revealed thermal niche separation, spatiotemporal segregation, and distinct community associations of the 3 molid species. Our quantitative findings suggest that the common mola is a more temperate species, while slender and sharptail mola are more (sub)tropical species, and that slender (and possibly also sharptail) mola undergo spawning migrations to the region around the Hawaiian Islands. In addition, we identified potential effects of fishing gear type on molid catch probability, an increasing trend in catch probability of a vulnerable species perhaps related to a shift in the distribution of fishing effort, and the possible presence in the fishery of a fourth molid species being misidentified as a congener, all of which are important conservation considerations for these enigmatic fishes.
\end{abstract}

KEY WORDS: Mola mola $\cdot$ Masturus lanceolatus $\cdot$ Ranzania laevis $\cdot$ Bycatch $\cdot$ Species distribution modeling $\cdot$ Longline

\section{INTRODUCTION}

Fishes in the family Molidae (molids, commonly known as ocean sunfishes or molas) are enigmatic, and scientific perceptions of these species have changed dramatically in recent years as they have received increased research attention (e.g. Pope et al. 2010, Phillips et al. 2015, Nyegaard et al. 2018b). Easily recognized by their lack of a caudal fin (Johnson \& Britz 2005), molids constitute an evolutionary exception within the order Tetraodontiformes be-

${ }^{*}$ Corresponding author: marosteg@uw.edu

$\S$ Article was changed to Open Access, and the copyright notice updated after publication.

This corrected version: February 5, 2021 cause their family is the only one that primarily diversified into the open ocean rather than fresh/brackish, coastal, or deep shelf waters (Yamanoue et al. 2008). The family consists of 3 genera (Mola, 3 species; Masturus, 1 species; and Ranzania, 1 species) (Froese \& Pauly 2019) and is circumglobally distributed in neritic and oceanic waters from tropical to temperate latitudes (Nyegaard et al. 2018a, Sawai et al. 2018).

There is notable diversity among molids, as a closer evolutionary relationship between Mola and Masturus than of either of these to Ranzania is supported

(C) The authors 2021. Open Access under Creative Commons by Attribution Licence. Use, distribution and reproduction are unrestricted. Authors and original publication must be credited.

Publisher: Inter-Research · www.int-res.com 
by phylogenetic (Yamanoue et al. 2004, Bass et al. 2005) and morphological studies (Santini \& Tyler 2002, Katayama \& Matsuura 2016). The species of Mola and Masturus achieve maximum sizes of $3+\mathrm{m}$ in length (Hutchins 2001), whereas Ranzania only reaches $<1 \mathrm{~m}$ in length (Smith et al. 2010). There are also marked differences in the dietary specialization (Bakenhaster \& Knight-Gray 2016, Nyegaard et al. 2017) and early development (Lyczkowski-Shultz 2003) of Mola and Masturus versus Ranzania, which suggests ecological divergence among these species.

While knowledge of individual molid species has increased in recent years, little is known of the environmental niche separation and differences in the reproductive or movement ecology of molids in sympatry. Limited evidence suggests that molid species exhibit distinct distributions in relation to sea surface temperature (SST) and latitude in the western South Pacific (Nyegaard et al. 2018b), segregated spawning activity in the western North Atlantic (Hellenbrecht et al. 2019), and different patterns in seasonal abundance in the Mediterranean Sea (Dulčić et al. 2007). Comparisons of molids in allopatry have noted potential differences in their environmental preferences or behavior but were confounded by the disparate regions or oceans in which the underlying studies were conducted (e.g. Dewar et al. 2010). Thus, there is a need for further research into the habitat use and ecological separation of molids in sympatry; however, such data are difficult to procure given the lengthy migrations (Potter et al. 2011), deep vertical descents (Phillips et al. 2015, Thys et al. 2017), low densities (Houghton et al. 2006), and rarely encountered aggregations of these fishes in remote waters (Castro \& Ramos 2002, Horn et al. 2016).

Interaction with commercial fisheries is a primary conservation concern for molids, yet at the same time represents a source of valuable information on their distribution, behavior, and life history (e.g. Castro \& Ramos 2002, Liu et al. 2009, Nakamura \& Sato 2014). Molids are primarily taken as bycatch in pelagic driftnet (Silvani et al. 1999, Horn et al. 2016, Hahlbeck et al. 2017) and longline fisheries across the globe (Coelho et al. 2012, Domingo et al. 2012, Nyegaard et al. 2018a) and are only rarely targeted for commercial harvest (Sagara \& Ozawa 2002, Liu et al. 2009). In the eastern North Pacific, at least 3 molid species are exposed to fishery interactions: common mola Mola mola, the most studied species in the family (Pope et al. 2010), as well as sharptail mola Masturus lanceolatus and slender mola Ranzania laevis, for which comparatively little information is available. In particular, these species are captured as bycatch in the $\sim 150$ vessel fleet of the Hawaiian longline fishery, which is the largest fishery managed under the US Western Pacific Regional Fishery Management Council. The Hawaiian longline fishery conducts $>1000$ trips $\mathrm{yr}^{-1}$ (Pan \& Walden 2015) over an area spanning more than $50^{\circ}$ in longitude and $45^{\circ}$ in latitude, enabling sampling of rare and highly migratory species. Long-term data from federal observers of this fishery, established for the quantification of protected species bycatch (e.g. sea turtles), have been used to document distributions (Walsh et al. 2009, Gilman et al. 2012), environmental associations (Walsh \& Kleiber 2001) and temporal population trends of pelagic species (Brodziak \& Walsh 2013, Walsh \& Brodziak 2015), as well as ecosystem changes (Polovina et al. 2009, Polovina \& Woodworth-Jefcoats 2013).

The purpose of this study was to investigate spatiotemporal dynamics in the distribution of common, sharptail, and slender mola in the eastern North Pacific. There have been qualitative, global comparisons of these 3 species (e.g. Gudger 1937) but no quantitative, regional assessments critically analyzing their distributional differences and the underlying drivers. We hypothesized species-specific, latitudinal distributions varying with seasonal thermal cycles and temporally distinct migrations, among species, to areas previously identified as spawning hotspots. We used $24 \mathrm{yr}$ of observer data from the Hawaiian longline fishery to determine thermal associations, model distributions, identify migrations, and characterize associated fish communities for each species. Our quantitative findings included spatiotemporal segregation, environmental niche separation, distinct community associations, and potential spawning migrations. In addition, we identified potential effects of fishing gear type on molid catch probability, an increasing trend in catch probability for a vulnerable species, and the possible presence in the fishery of a fourth molid species being misidentified as a congener.

\section{METHODS}

\subsection{Fishery observer data}

The Hawaiian longline fishery is divided into 2 sectors (deep-set and shallow-set) with disparate fishing methodologies and spatial distributions. The deepand shallow-set sectors are legally defined by the number of hooks used between floats on the longline (deep-set $\geq 15$; shallow-set $<15$ ), as using more hooks per float results in a deeper fishing depth (Depart- 
ment of Commerce 2004). The deep-set sector primarily fishes at 100-400 $\mathrm{m}$ depth during the daytime in (sub)tropical waters from $5^{\circ}-35^{\circ} \mathrm{N}$ to target tunas (Thunnus spp. and skipjack tuna Katsuwonus pelamis), whereas the shallow-set sector primarily fishes at $<60 \mathrm{~m}$ depth during the nighttime in temperate waters from $28^{\circ}-32^{\circ} \mathrm{N}$ to target swordfish Xiphias gladius (Bigelow et al. 2006, Brodziak \& Walsh 2013, Woodworth-Jefcoats et al. 2018). The catchability of various pelagic fishes changes with depth and diel period due to their distinct diurnal and nocturnal movement patterns, with certain species being more vulnerable to daytime, deep-set operations than nighttime, shallow-set operations (and vice versa) depending on the degree of overlap between fishing gear and species' vertical distributions (He et al. 1997, Ward \& Myers 2005). Observer coverage of deep-set sector effort was $~ 4 \%$ from 1995-2000 but increased to $20 \%$ in 2001 and has remained at that required level since (NMFS 2010, WoodworthJefcoats et al. 2018), whereas coverage of shallow-set sector effort ranged from $\sim 5-25 \%$ in the years prior to a 2001-2004 emergency fishery closure but has been $100 \%$ since (Walsh et al. 2005, Gilman et al. 2007, Howell et al. 2008). Observers record the date, time, and location of all effort, the number of hooks set, number of hooks per float, bait type, and hook type for each longline set, as well as the visually determined species identification and number of all fish captured. In addition, observers measure every third fish caught (since February 2006), providing an actual fork length measurement when the fish can safely be brought on board or an estimated fork length when it cannot. Catch rates of species recorded in both the observer dataset and commercial vessel logbooks are highly correlated (Polovina et al. 2009), indicating that the observed portion of the fishery adequately represents the fishery at large. We used observer data from the eastern North Pacific (east of $180^{\circ} \mathrm{W}$, north of the equator) as the Hawaiian longline fishery occurs almost exclusively within this region (only $0.1 \%$ of longline sets occurred elsewhere during the 24 yr study period).

It is important to note that, while the 3 genera of molids (Mola, Masturus, and Ranzania) are easily distinguished by their external morphology, the currently valid taxonomy of the genus Mola was not established until the last year of the study period (Nyegaard et al. 2018b, Sawai et al. 2018). Of the 3 species now recognized in the genus Mola, M. tecta is thought to occur almost exclusively in temperate waters of the southern hemisphere (Nyegaard et al. 2018a,b) but a few individuals have been recorded along the coast of California, USA, in the eastern North Pacific (e.g. Walker et al. 2020). In contrast, both M. mola and M. alexandrini are thought to regularly occur in both hemispheres in the Pacific Ocean (Yoshita et al. 2009, Sawai et al. 2018). While documented extensively in the western North Pacific, the only genetically verified $M$. alexandrini recorded in the eastern North Pacific were sampled in the Galápagos Islands (Thys et al. 2013, Sawai et al. 2018). Thus, we know little about this species in the study region, and it is possible that some of the fish identified as M. mola by Hawaiian longline observers prior to the taxonomic revision of the genus were in fact M. alexandrini. Limited data on these 2 species in sympatry suggest that $M$. mola may occupy a cooler thermal niche than M. alexandrini (Sawai et al. 2011, Nyegaard et al. 2018a, Chang et al. 2020). Also, while the federal observer program has counted sharptail mola separately from the other molid species since 2004 when positive photographic identification of the species was first provided by an observer, this species was likely aggregated with the more frequently encountered common mola prior to 2004 (S. Arceneaux pers. comm.).

\subsection{Oceanographic data}

SST at the date and location of each longline set was extracted from the National Oceanic and Atmospheric Administration (NOAA) Optimum Interpolation 1/4 Degree Daily SST (OISST) Analysis, Version 2 (Reynolds et al. 2008) for assessment of molid thermal associations. Temperature at depths approximating the medians of the vertical distributions of the shallow-set $(45 \mathrm{~m})$ and deep-set $(262 \mathrm{~m})$ sectors was similarly extracted from the National Centers for Environmental Prediction (NCEP) Global Ocean Data Assimilation System (GODAS) (Behringer \& Xue 2004), to investigate thermal patterns at the points in the water column where molas are captured in the fishery. To explore the influence of temperature on the spatial and intra-annual distribution of molids, both overall and monthly climatologies of SST and temperatures at 45 and $262 \mathrm{~m}$ were constructed in the study region for the period 1 January 1995 to 31 December 2018.

\subsection{Species distribution modeling}

We constructed species distribution models from longline presence/absence data to investigate spatio- 
temporal segregation of common, sharptail, and slender mola. Catches of each mola species per longline set were converted to binary values to inform generalized additive models using a binomial distribution and logit link. Two models were constructed for common mola, one using only deep-set data and a second using only shallow-set data, due to the disparate spatial distribution of effort as well as time and depth of gear deployment in these sectors (Table 1). Models for sharptail and slender mola solely used deep-set data due to their nearly exclusive occurrence in this sector (Table 1).

To explore the primary hypotheses regarding the distribution of the mola species, we tested a model term for spatiotemporal variation (bivariate tensor product of month and latitude) that quantifies intraannual shifts in distribution along a north-south axis. A potential gear effect was tested for fishing depth (proxied by a univariate smooth of hooks per float). An interannual effect was tested (factor for year) from 1995-2018 for deep-set common mola and slender mola, 1995-2000 and 2005-2018 for shallow-set common mola, and 2004-2018 for sharptail mola (Table 1). The gap in years tested in the model of shallow-set common mola is due to the emergency closure of that fishery sector from March 2001-April 2004. The shorter year-span for sharptail mola is due to the observer program not beginning to tally that species until 2004. Hook type and bait type could not be included in any models due to high collinearity with year in both the deep- and shallow-set sectors (Pearson correlation coefficients $>10.4 \mid$ ). These collinearities are the result of regulatory changes during the study period requiring the use of circle hooks in both fishery sectors and banning the use of squid bait in the shallow-set sector (which led fishers to willingly cease using squid bait in the deep-set sector). Furthermore, latitude and SST exhibited high collinearity over the broad spatial domain of the study region (Pearson correlation coefficients $>|0.5|$ ), precluding inclusion of both variables in the models. Thus, we could either include latitude in the model and explain the underlying temperatures or include

Table 1. Summary of input data for mola species distribution models. Presences represent the number of longline sets with positive catch, and absences represent the number of longline sets with zero catch

\begin{tabular}{|lcccc|}
\hline Species & Sector & Years & Presences & Absences \\
\hline Common mola & Deep-set & $1995-2018$ & 441 & 65045 \\
Common mola & Shallow-set & $1995-2000,2005-2018$ & 574 & 18872 \\
Sharptail mola & Deep-set & $2004-2018$ & 230 & 53843 \\
Slender mola & Deep-set & $1995-2018$ & 3221 & 62265 \\
\hline
\end{tabular}

temperature in the model and explain its latitudinal distribution; we chose the former to directly assess potential spatial overlap or segregation of molid species and facilitate identification of migrations in the study region. All models included an offset of the logtransformed number of hooks to account for variation in the number of hooks per longline set-this term was always retained and not subjected to model selection. Smooth terms for latitude and hooks per float used a thin-plate regression spline while that for month used a cyclic cubic regression spline (ensuring continuity from December to January). Models were constructed via forward selection with Akaike's information criterion (AIC), which identifies better models with lower scores (Akaike 1974), as well as AIC weight, which measures the probability of a model being the best among those tested (Wagenmakers \& Farrell 2004). Model performance was assessed using the area under the receiver operating curve (AUC), which is a measure, ranging from $0-1$, of how well a model predicts the outcome, with scores $>0.5$ indicating that a model provides better than random predictions (Hanley \& McNeil 1982). Models with AUC scores of 0.7-0.9 are considered useful, and those with scores $>0.9$ are considered highly accurate (Swets 1988). Models were built in $\mathrm{R}$ version 3.6.1 (R Core Team 2019) using the 'mgcv' package (Wood 2019).

\subsection{Community ecology}

To assess ecological segregation among the mola species, we conducted a principal component analysis (PCA) on the catch composition of the $85000+$ longline sets observed in the fishery. We used counts of the 15 most abundant species captured across the deep- and shallow-set sectors as descriptors. These 15 non-mola species represented variation along the tropical-temperate and epipelagic-mesopelagic axes, and included - in decreasing order of abundancelongnose lancetfish Alepisaurus ferox, bigeye tuna Thunnus obesus, blue shark Prionace glauca, common dolphinfish Coryphaena hippurus, swordfish, snake mackerel Gempylus serpens, sickle pomfret Taractichthys steindachneri, escolar Lepidocybium flavobrunneum, yellowfin tuna Thunnus albacares, skipjack tuna, albacore Thunnus alalunga, opah (Lampris spp.), wahoo Acanthocybium solandri, striped marlin Kajikia audax, and shortbill spearfish Tetrapturus angustirostris. We 
used a Hellinger transformation on the catch data, as recommended for ordination of abundance data containing many zeros (Legendre \& Gallagher 2001), and conducted the PCA on the variance-covariance matrix because units were shared and scales were similar among all descriptors. We assessed the significance of the eigenvalues of the first 2 principal components (PCs) with a Monte Carlo randomization test. PCA was conducted with the 'stats' package (R Core Team 2019) and the 'biostats' R collection (McGarigal 2016).

\section{RESULTS}

\subsection{Catch metrics}

Molas are rare catches in the Hawaiian longline fishery; they constitute only $0.2 \%$ of the catches of all species (by number) when summed across the observed deep- and shallow-set sectors. Likewise, only $5.3 \%$ of the $85000+$ longline sets observed across the sectors from 1995-2018 resulted in a catch of at least 1 mola species. Catch of common mola was nearly equally distributed among the observed deep- and shallow-set sectors, although the catch per set, nominal CPUE, and percentage of sets with positive catches were higher in the shallow-set sector (Table 2). The length of common mola captured in deep- and shallow-sets, on average $( \pm \mathrm{SD})$, was estimated to be $1.5 \pm 0.3 \mathrm{~m}$ (range: $0.6-2.9 \mathrm{~m}, \mathrm{n}=72$ ) and $1.5 \pm 0.4 \mathrm{~m}$ (range: $0.9-2.4 \mathrm{~m}, \mathrm{n}=122$ ), respectively.
In contrast, the deep-set sector yielded nearly all the catch, as well as higher catch per set, nominal CPUE, and percentage of sets with positive catches than the shallow-set sector for both sharptail and slender mola (Table 2). The length of sharptail mola captured in deep-sets, on average, was estimated to be $1.4 \pm 0.4 \mathrm{~m}$ (range: $0.9-2.1 \mathrm{~m}, \mathrm{n}=48$ ) and the length of slender mola captured in deep-sets, on average, was measured to be $0.51 \pm 0.06 \mathrm{~m}$ (range: $0.25-0.96 \mathrm{~m}, \mathrm{n}=$ 1075). The actual measurement (not an estimate) of a $0.96 \mathrm{~m}$ slender mola by a fishery observer represents the largest individual of the species ever recorded. Among sets with positive catches, sharptail and common mola catches rarely consisted of multiple individuals ( 0.4 and $5.6 \%$, respectively), whereas slender mola catches frequently consisted of multiple individuals $(39.8 \%)$, as many as 22 molas per set. Furthermore, only $0.06 \%$ of sets with positive mola catches yielded 2 mola species, and none yielded all 3 ; these limited instances of overlapping mola species in the catch exclusively occurred in the deep-set sector.

The 3 mola species exhibited distinct spatial distributions of catch across the eastern North Pacific (Fig. 1). Common mola were caught from $4.3^{\circ}-$ $41.8^{\circ} \mathrm{N}$ and $176.5^{\circ}-125.2^{\circ} \mathrm{W}$, but were primarily encountered in the area around the Hawaiian Islands and offshore of the southwestern continental USA; the latter area exhibited particularly high catch relative to the local effort. Sharptail mola were captured from $4.7^{\circ}-37.1^{\circ} \mathrm{N}$ and $177.5^{\circ}-134.3^{\circ} \mathrm{W}$, with their catch distribution largely reflecting the distri-

Table 2. Summary metrics of the 3 mola species observed across fishery sectors and separately in the deep- and shallow-set sectors from 1995-2018. Catch per set and nominal catch per unit effort (CPUE, per 1000 hooks) are provided as averages (with SD in parentheses)

\begin{tabular}{|c|c|c|c|c|}
\hline Fishery metric & Sector & Common mola & Sharptail mola & Slender mola \\
\hline \multirow[t]{3}{*}{ Catch (n) } & Both & 1099 & 249 & 6165 \\
\hline & Deep-set & 469 & 231 & 6141 \\
\hline & Shallow-set & 630 & 18 & 24 \\
\hline \multirow[t]{3}{*}{ Catch per set } & Both & $0.013(0.123)$ & $0.003(0.059)$ & $0.072(0.500)$ \\
\hline & Deep-set & $0.007(0.091)$ & $0.004(0.066)$ & $0.094(0.569)$ \\
\hline & Shallow-set & $0.032(0.193)$ & $0.001(0.032)$ & $0.001(0.044)$ \\
\hline \multirow[t]{3}{*}{ Nominal CPUE } & Both & $0.010(0.106)$ & $0.002(0.029)$ & $0.033(0.225)$ \\
\hline & Deep-set & $0.003(0.042)$ & $0.003(0.029)$ & $0.043(0.255)$ \\
\hline & Shallow-set & $0.033(0.205)$ & $0.001(0.030)$ & $0.001(0.052)$ \\
\hline \multirow[t]{3}{*}{ Sets with zero catches (\%) } & Both & 98.8 & 99.7 & 96.2 \\
\hline & Deep-set & 99.3 & 99.6 & 95.1 \\
\hline & Shallow-set & 97.1 & 99.9 & 99.9 \\
\hline \multirow[t]{3}{*}{ Sets with positive catches (\%) } & Both & 1.2 & 0.3 & 3.8 \\
\hline & Deep-set & 0.7 & 0.4 & 4.9 \\
\hline & Shallow-set & 2.9 & 0.1 & 0.1 \\
\hline
\end{tabular}




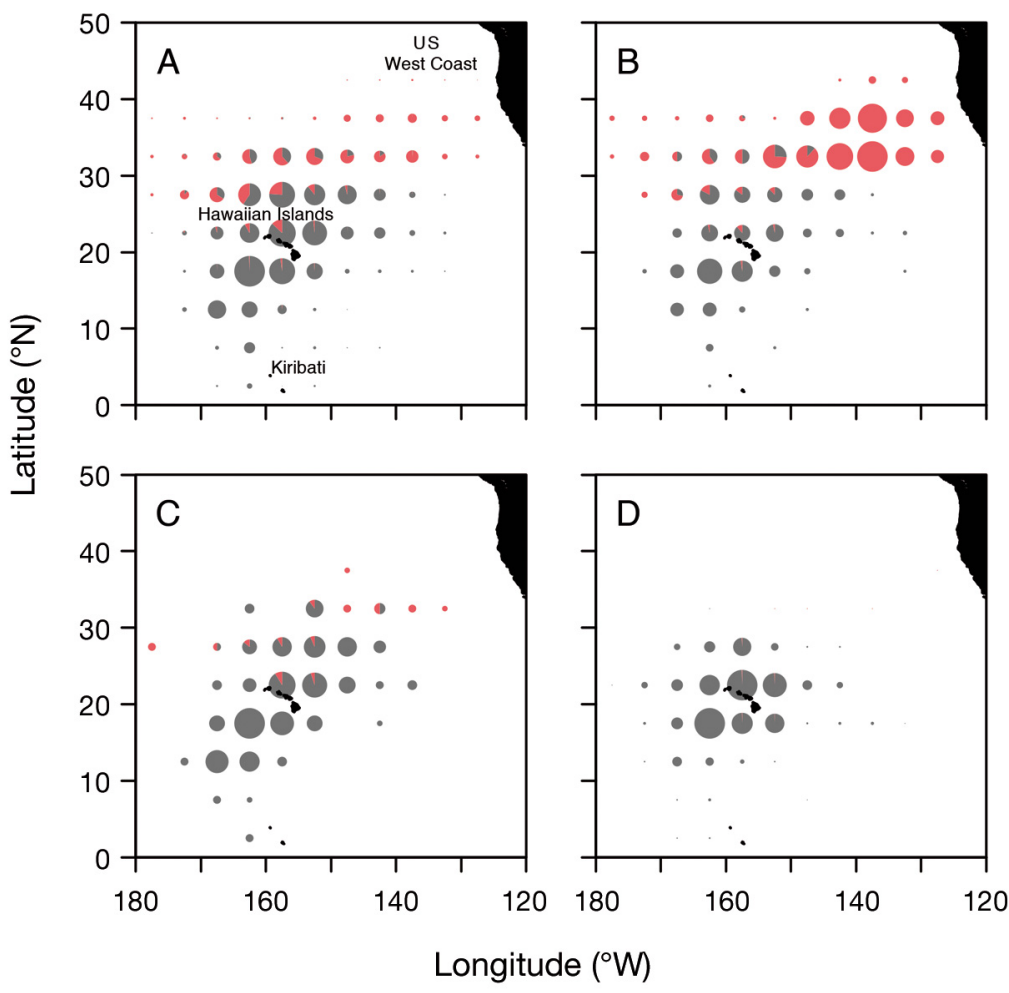

Fig. 1. Distribution of (A) observed effort, and catches of (B) common mola, (C) sharptail mola, and (D) slender mola in the Hawaiian longline fishery from 1995-2018 at $5^{\circ}$ resolution. Effort is the number of longline sets and catch is the number of individuals. Sector contributions are color coded (grey: deep-set; red: shallow-set). Point sizes are scaled relative to the maximum value of each respective panel. Note that any $5^{\circ} \times 5^{\circ}$ area within which $<3$ unique vessels operated is excluded from these plots for the purpose of location data confidentiality

bution of effort except at high latitudes where they were less present. Slender mola were captured from $2.0^{\circ}-35.5^{\circ} \mathrm{N}$ and $175.1^{\circ}-127.5^{\circ} \mathrm{W}$, predominantly in the close vicinity of the Hawaiian Islands. In the region from $30^{\circ}-40^{\circ} \mathrm{N}$ and $155^{\circ}-125^{\circ} \mathrm{W}$, where the majority of common mola but few sharptail and slender mola were captured, the average temperatures at 0 (sea surface), 45 (median shallow-set depth), and $262 \mathrm{~m}$ (median deep-set depth) were 13$22,11-20$, and $8-13^{\circ} \mathrm{C}$, respectively (Fig. $2 \mathrm{~A}, \mathrm{C}, \mathrm{E}$ ). In the region from $10^{\circ}-30^{\circ} \mathrm{N}$ and $170^{\circ}-150^{\circ} \mathrm{W}$, where a plurality of common mola and the majority of sharptail and slender mola were captured, the average temperatures at 0,45 , and $262 \mathrm{~m}$ were $22-28$, 20-27, and $10-13^{\circ} \mathrm{C}$, respectively (Fig. $2 \mathrm{~A}, \mathrm{C}, \mathrm{E}$ ). SST ranges recorded for the 3 species were similar (common mola: $15.3-29.5^{\circ} \mathrm{C}$; sharptail mola: $15.6-29.0^{\circ} \mathrm{C}$; slender mola $17.1-28.9^{\circ} \mathrm{C}$ ), but their ranges of increased association (where the density of catches exceeded that of fishing effort) were distinct (Fig. 3). Relative to the density of effort, common mola catches were highest at SSTs from approximately $15-19^{\circ} \mathrm{C}$, sharptail mola catches were highest from $24-28^{\circ} \mathrm{C}$, and slender mola catches were highest from $22-26^{\circ} \mathrm{C}$. In comparison, common mola exhibited a broadly temperate to tropical catch distribution, whereas sharptail and slender mola exhibited more (sub)tropical catch distributions.

\subsection{Species distribution modeling}

The best-fit model for each mola species suggested spatiotemporal patterns in their eastern North Pacific distribution, as well as interannual (and, in some instances, gear-related) effects. For common mola in the deep-set sector, the top model included the tensor product of latitude and month, the factor for year, plus the smooth of hooks per float (Table 3), and exhibited an explained deviance of $5.5 \%$ and an AUC score of 0.71 . The spatiotemporal pattern suggested that common mola catch probability was highest north of $25^{\circ} \mathrm{N}$ from October-February, shifted north of $35^{\circ} \mathrm{N}$ from March-June, and then returned southward from JulySeptember (Fig. 4A). Additionally, there was a secondary area of high (but comparatively lower) catch probability from $\sim 10^{\circ}-20^{\circ} \mathrm{N}$ that was variable throughout the year. Catch probability was consistently lowest south of $10^{\circ} \mathrm{N}$. Among deep-sets, the shallowest deployments (i.e. with fewer hooks per float) yielded higher catch probability than those of intermediate depth (see Fig. S1 in the Supplement at www.int-res.com/articles/suppl/ m654p109_supp.pdf). No linear interannual trend in catch probability was present in a regression of the back-transformed, year-specific intercepts from the species distribution model $(p=0.11)$.

For common mola in the shallow-set sector, the top model included the tensor product of latitude and month, the factor for year, and the smooth of hooks per float (Table 3), and exhibited an explained deviance of $17.5 \%$ and an AUC score of 0.84 . The spatiotemporal pattern suggested that common mola catch probability was highest north of $28^{\circ} \mathrm{N}$ from OctoberFebruary, shifted north of $35^{\circ} \mathrm{N}$ from March-May, and then returned southward from June-September (Fig. 4B). Catch probability was consistently lowest south of $28^{\circ} \mathrm{N}$ throughout the year (Fig. 4B). The term 


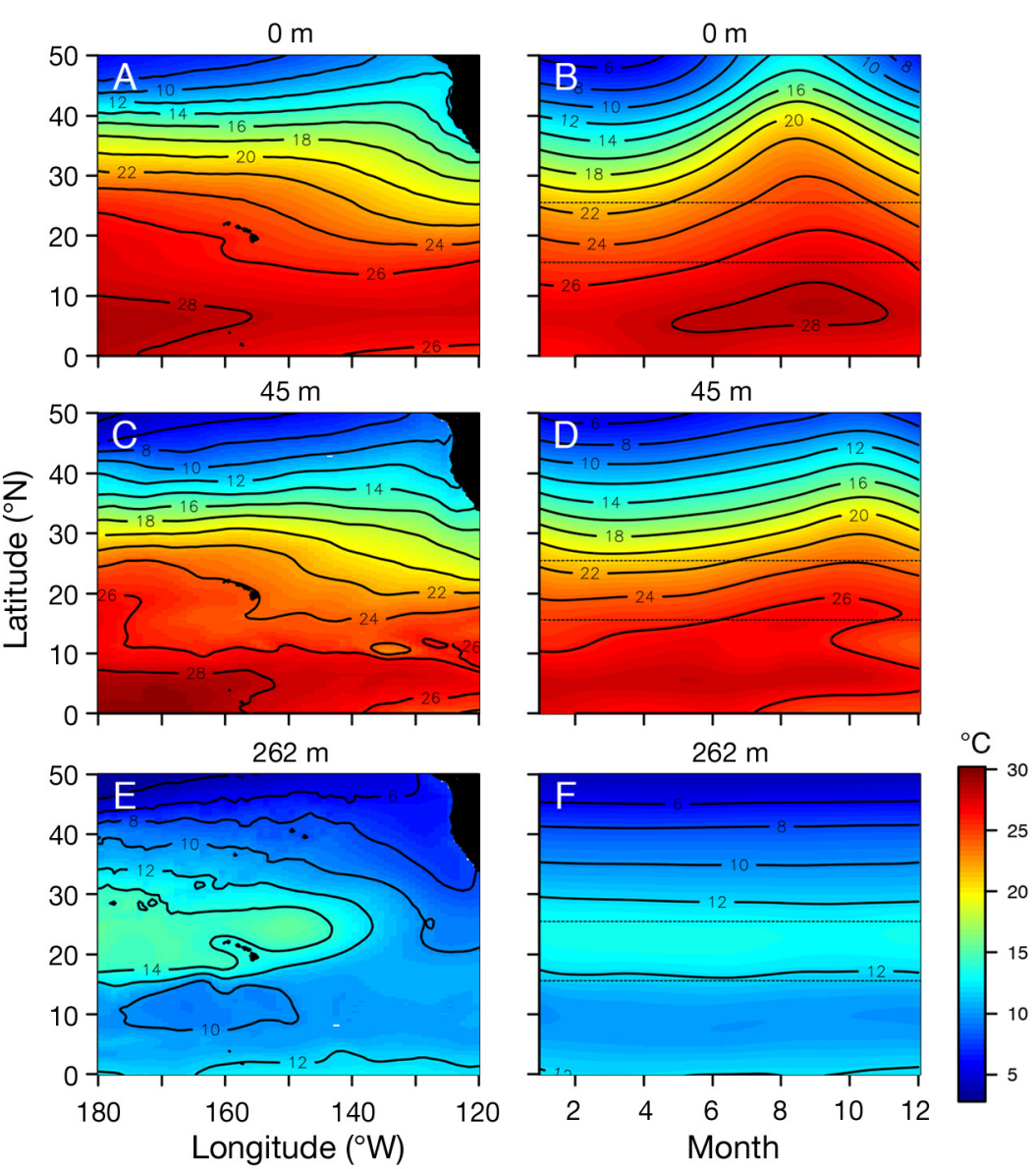

Fig. 2. Climatological average temperature by longitude and latitude (yearround) and month and latitude at (A,B) 0, (C,D) 45, and (E,F) $262 \mathrm{~m}$ depth in the eastern North Pacific from 1995-2018. In panels B, D, and F, the dashed horizontal lines indicate the latitudinal bounds of the US exclusive economic zone surrounding the 8 main Hawaiian Islands. The $0 \mathrm{~m}$ (sea surface) temperature data come from the NOAA 1/4 degree daily OISST analysis and the $45 \mathrm{~m}$ (median shallow-set sector depth) and $262 \mathrm{~m}$ (median deep-set sector depth) temperature data come from the NCEP GODAS analysis

for hooks per float improved model fit but did not have a significant effect on catch probability. The mean estimated catch probability was $>4$ times higher in the 6 yr prior to the fishery closure than in the 14 yr after the fishery closure, coinciding with bait and hook type regulation changes (Fig. 5). Linear regression revealed a significant increase in catch probability over time in the years after the fishery closure when no further bait or hook type regulations were enacted $(F=$ 27.2, $\mathrm{p}=0.0002, \mathrm{R}^{2}=0.67$ ). However, there was a concurrent eastward shift in longitude at which the sector was operating (i.e. an average of $1.1^{\circ}$ to the east per year: $F=2239$, p $<0.0001$, $\mathrm{R}^{2}=0.11$; Fig. S2).

For sharptail mola in the deepset sector, there were 2 competing models of similar relative probability according to AIC weight and similar predictive performance according to the AUC (Table 3). Among these, the most parsimonious model with the lowest number of terms included the tensor product of latitude and month, as well as the factor for year (Table 3), and exhibited an explained deviance of $2.7 \%$ and an AUC score of 0.67 . The spatiotemporal pattern suggested that sharptail mola catch probability was highest south of $16^{\circ} \mathrm{N}$ from December-March, expanded

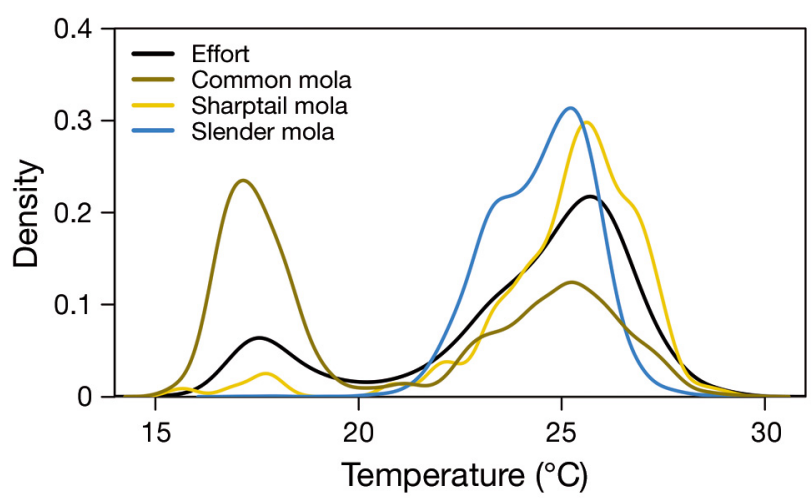

Fig. 3. Sea surface temperature (SST) distribution of mola catches relative to effort. Increased associations are indicated where catch density of a given species is greater than effort density. Decreased associations are indicated where catch density of a given species is less than effort density. Density estimates were calculated with a Gaussian smoothing kernel using a 0.35 bandwidth northward to south of $28^{\circ} \mathrm{N}$ from April-September, and then retracted southward from OctoberNovember (Fig. 4C). No linear interannual trend in catch probability was present in a regression of the back-transformed, year-specific intercepts from the species distribution model $(\mathrm{p}=0.06)$.

For slender mola in the deep-set sector, there were 2 competing models of similar relative probability according to AIC weight and equivalent predictive performance according to the AUC (Table 3). Among these, the most parsimonious model with the lowest number of terms included the tensor product of latitude and month, as well as the factor for year (Table 3), and exhibited an explained deviance of $35.1 \%$ and an AUC score of 0.91 . The spatiotemporal pattern suggested that slender mola catch probability was highest in the fishery between $\sim 10^{\circ}$ and $30^{\circ} \mathrm{N}$ from December-March, shifted southward to the equator 
Table 3. Species distribution model forward selection results, including the difference in Akaike's information criterion (AIC) relative to the model with the lowest score $(\triangle \mathrm{AIC})$, AIC weight (AICw), and area under the receiver operating curve (AUC). Model terms are represented as follows: o(): offset; $\mathrm{s}()$ : univariate smooth; te(): bivariate tensor product; f: factor

\begin{tabular}{|c|c|c|c|c|c|}
\hline Species & Sector & Model & $\Delta \mathrm{AIC}$ & $\mathrm{AICw}$ & AUC \\
\hline \multirow[t]{7}{*}{ Common mola } & \multirow{7}{*}{ Deep-set } & $o($ Hooks $)+$ te $($ Month, Latitude $)+$ fYear $+s($ Hooks Per Float $)$ & 0 & 0.98 & 0.71 \\
\hline & & o(Hooks) + te(Month, Latitude) + fYear & 7.7 & 0.02 & 0.70 \\
\hline & & $\mathrm{o}($ Hooks $)+$ te(Month, Latitude $)+\mathrm{s}$ (Hooks Per Float $)$ & 73.0 & 0 & 0.65 \\
\hline & & o(Hooks) + te(Month, Latitude) & 99.2 & 0 & 0.64 \\
\hline & & $\mathrm{o}($ Hooks $)+$ fYear & 106.5 & 0 & 0.64 \\
\hline & & o(Hooks $)+\mathrm{s}($ Hooks Per Float $)$ & 166.8 & 0 & 0.55 \\
\hline & & $\mathrm{o}($ Hooks $)$ & 191.9 & 0 & 0.48 \\
\hline \multirow{7}{*}{ Common mola } & \multirow{7}{*}{ Shallow-set } & o(Hooks $)+$ te $($ Month, Latitude $)+$ fYear + s(Hooks Per Float $)$ & 0 & 0.75 & 0.84 \\
\hline & & o(Hooks $)+$ te(Month, Latitude $)+$ fYear & 2.2 & 0.25 & 0.84 \\
\hline & & o(Hooks) + te(Month, Latitude $)+s($ Hooks Per Float $)$ & 139.4 & 0 & 0.81 \\
\hline & & $\mathrm{o}($ Hooks $)+$ te(Month, Latitude) & 150.1 & 0 & 0.81 \\
\hline & & $o($ Hooks $)+$ fYear & 668.4 & 0 & 0.67 \\
\hline & & $\mathrm{o}($ Hooks $)+\mathrm{s}($ Hooks Per Float $)$ & 806.5 & 0 & 0.60 \\
\hline & & o(Hooks) & 833.1 & 0 & 0.57 \\
\hline \multirow[t]{7}{*}{ Sharptail mola } & \multirow{7}{*}{ Deep-set } & $o($ Hooks $)+$ te $($ Month, Latitude $)+$ fYear & 0 & 0.51 & 0.67 \\
\hline & & $\mathrm{o}($ Hooks $)+$ te $($ Month, Latitude $)+$ fYear $+\mathrm{s}($ Hooks Per Float $)$ & 0.2 & 0.45 & 0.68 \\
\hline & & $\mathrm{o}($ Hooks $)+$ te(Month, Latitude $)+\mathrm{s}($ Hooks Per Float $)$ & 5.3 & 0.04 & 0.64 \\
\hline & & o(Hooks) + te(Month, Latitude) & 8.8 & 0.01 & 0.63 \\
\hline & & $o($ Hooks $)+$ fYear & 23.9 & 0 & 0.62 \\
\hline & & $\mathrm{o}($ Hooks $)+\mathrm{s}($ Hooks Per Float $)$ & 26.1 & 0 & 0.56 \\
\hline & & $\mathrm{o}($ Hooks $)$ & 28.5 & 0 & 0.54 \\
\hline \multirow[t]{7}{*}{ Slender mola } & \multirow[t]{7}{*}{ Deep-set } & $\mathrm{o}($ Hooks $)+$ te $($ Month, Latitude $)+$ fYear + s(Hooks Per Float $)$ & 0 & 0.61 & 0.91 \\
\hline & & $\mathrm{o}($ Hooks $)+$ te(Month, Latitude) + fYear & 0.9 & 0.39 & 0.91 \\
\hline & & o(Hooks) + te(Month, Latitude) + s(Hooks Per Float) & 457.6 & 0 & 0.90 \\
\hline & & o(Hooks) + te(Month, Latitude) & 487.5 & 0 & 0.90 \\
\hline & & $o($ Hooks $)+$ fYear & 8348.8 & 0 & 0.61 \\
\hline & & $\mathrm{o}($ Hooks $)+\mathrm{s}($ Hooks Per Float $)$ & 8820.0 & 0 & 0.53 \\
\hline & & o(Hooks) & 8949.0 & 0 & 0.52 \\
\hline
\end{tabular}

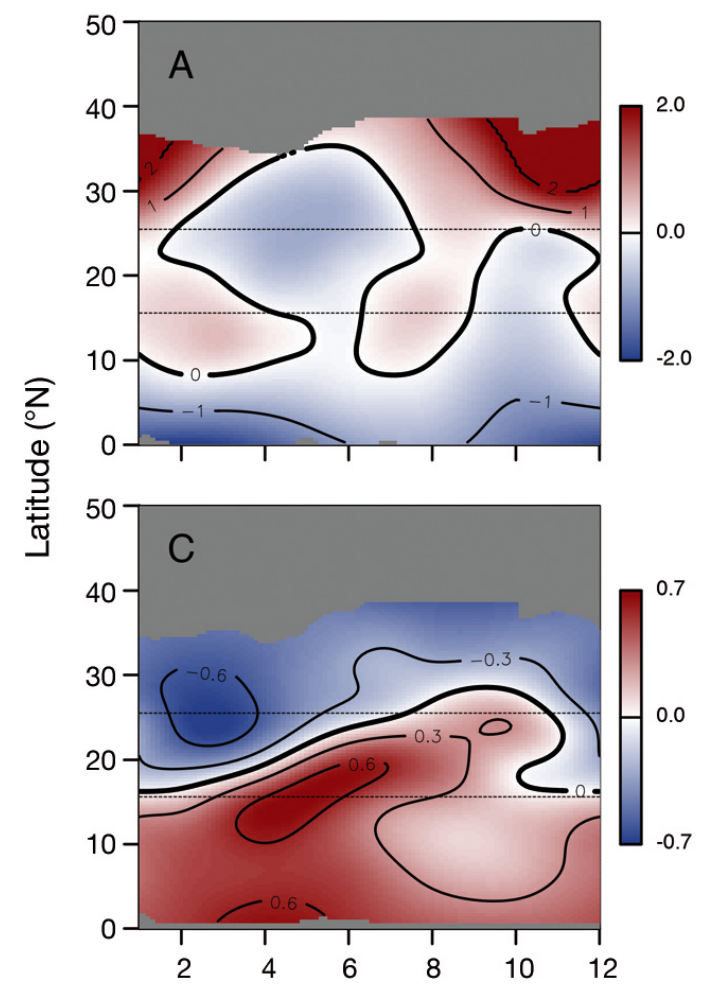

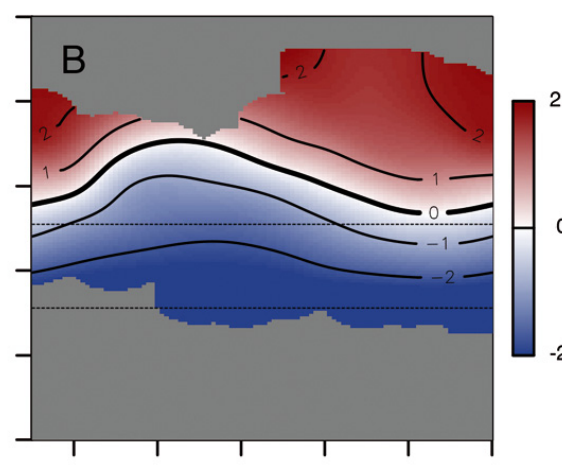

Fig. 4. Spatiotemporal partial effects on the catch probability of (A) common mola in the deep-set sec2.3 tor, (B) common mola in the shallow-set sector, (C) sharptail mola in the deep-set sector, and (D) slender mola in the deep-set sector. These bivariate tensor products of month and latitude are presented at the scale of the linear predictor. Red 2.3 denotes month/latitude combinations of relatively increased catch probability, blue denotes month/ latitude combinations of relatively decreased catch probability, and grey denotes when/where no proximal data were available. Note the

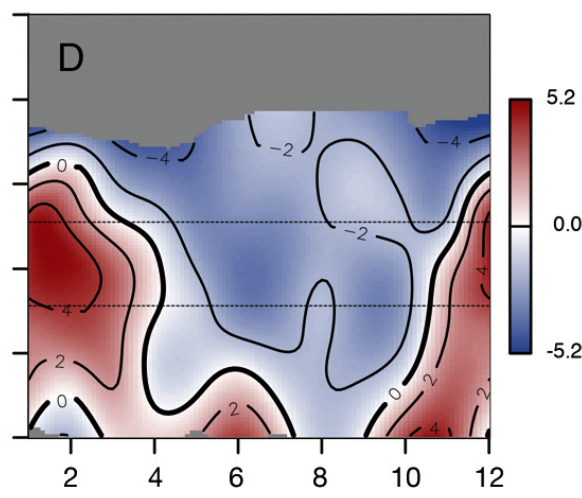
different effect ranges among models: larger effect ranges indicate greater relative differences in catch probability. In this plot, effect ranges are truncated at the extremes to ensure equal color gradient discernment above and below the zero centers. The dashed horizontal lines indicate the latitudinal bounds of the US exclusive economic zone surrounding the 8 main Hawaiian Islands 


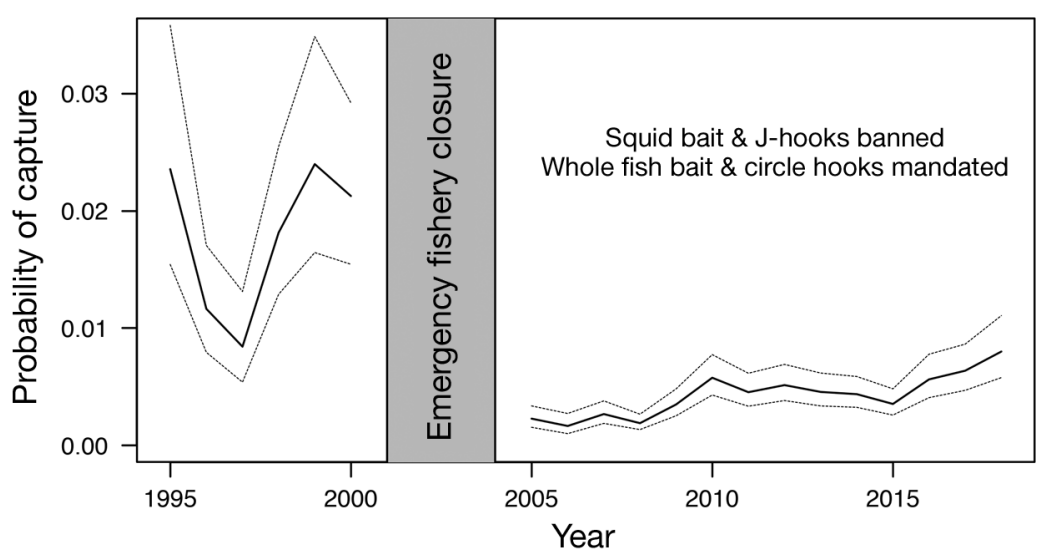

Fig. 5. Model-predicted probability of common mola capture by a shallow-set longline from 1995-2000 and 2005-2018. The solid line is the mean estimated probability and the dashed lines represent \pm 1 SE. Predictions were made using the median latitude, month, total number of hooks, and hooks per float in the sector across the full study period. No bait or hook type regulations were in place prior to the fishery closure, but squid bait and J-hooks were banned and whole fish bait and circle hooks were mandated in the sector once it reopened. Greater uncertainty of the year-specific estimates from 1995-2000 than those from 2005-2018 is due to the relatively lower fishing effort and observer coverage in the sector in the years prior to the closure from April-June, became particularly low across the entire region from July-September, and then increased northward from the equator from October-November (Fig. 4D). Also, the catch probability was always low north of $32^{\circ} \mathrm{N}$. No linear interannual trend in catch probability was present in a regression of the back-transformed, yearspecific intercepts from the species distribution model $(\mathrm{p}=0.39)$.

\subsection{Community ecology}

PC1 explained $28.4 \%$ of the variance in the community dataset (eigenvalue randomization test: $\mathrm{p}<0.001$ ), while PC2 explained 13.0\% (eigenvalue randomization test: $\mathrm{p}<0.001$ ) (Fig. 6). The variation in catch composition along PC1 primarily reflected a tropical (deep-set)-temperate (shallow-set)

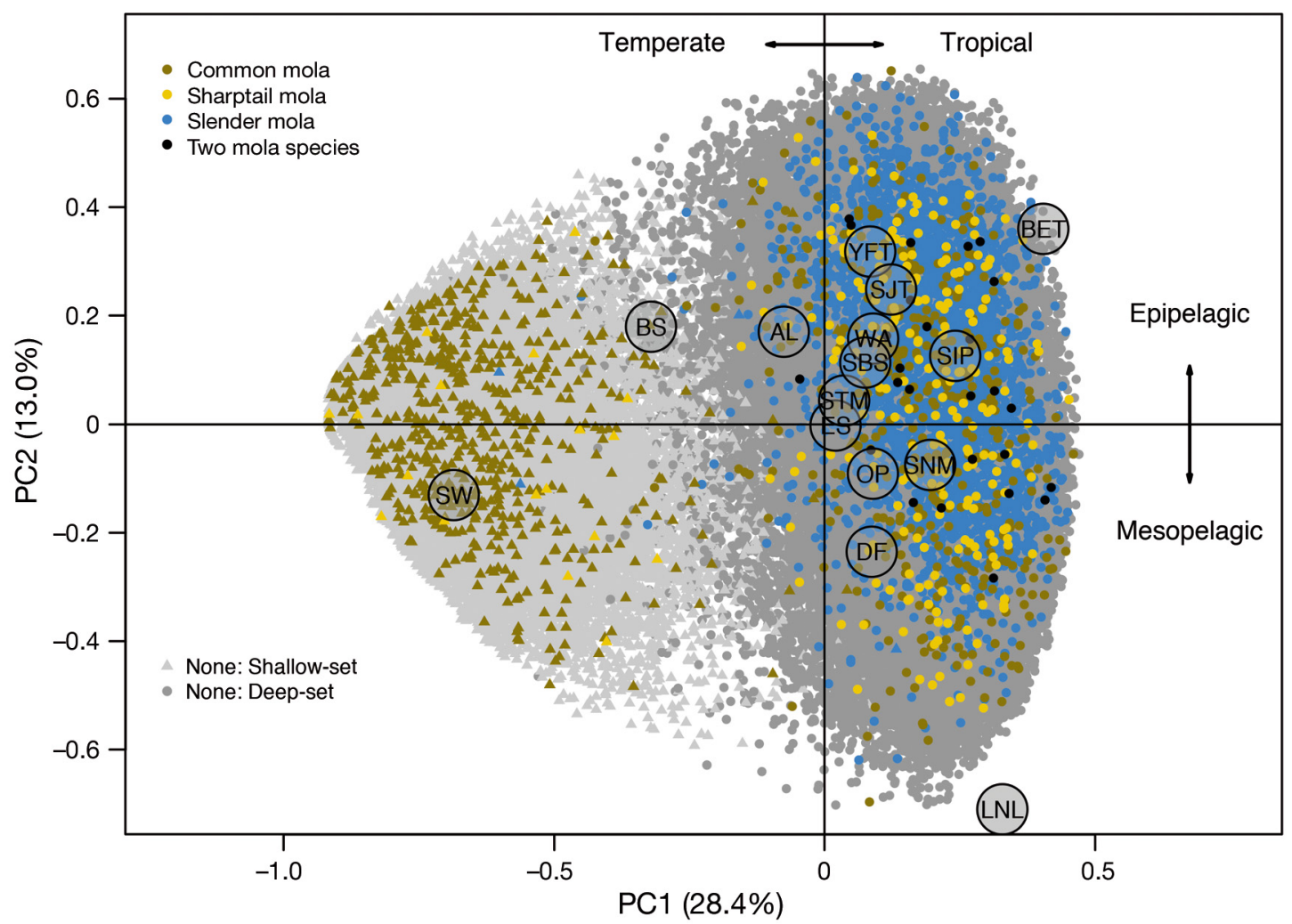

Fig. 6. PCA of the community composition of non-mola fish species captured on longline sets. Points are color coded by the mola species for which there was positive catch on that particular set, or by sector if no molas were caught. Shaded circles with inset abbreviations indicate eigenvectors of the corresponding species along PC1 and PC2. See Table 4 for full species names. Labeled arrows indicate primary axes of differentiation 
Table 4. Pearson correlations of each non-mola species with the longline-set scores along principal component (PC) 1 and 2; relationships may be positive or negative, and greater absolute values indicate stronger relationships. Species are listed in decreasing order of abundance when summed across the observed deep- and shallow-set sectors

\begin{tabular}{|lcrr|}
\hline Species & Abbreviation & PC1 & PC2 \\
\hline Longnose lancetfish & LNL & 0.51 & -0.74 \\
Bigeye tuna & BET & 0.67 & 0.40 \\
Blue shark & BS & -0.60 & 0.23 \\
Common dolphinfish & DF & 0.16 & -0.28 \\
Swordfish & SW & -0.93 & -0.12 \\
Snake mackerel & SNM & 0.40 & -0.10 \\
Sickle pomfret & SIP & 0.48 & 0.17 \\
Escolar & ES & 0.05 & -0.00 \\
Yellowfin tuna & YFT & 0.19 & 0.49 \\
Skipjack tuna & SJT & 0.30 & 0.41 \\
Albacore & AL & -0.19 & 0.28 \\
Opah & OP & 0.28 & -0.19 \\
Wahoo & WA & 0.28 & 0.33 \\
Striped marlin & STM & 0.11 & 0.09 \\
Shortbill spearfish & SBS & 0.25 & 0.25 \\
\hline
\end{tabular}

axis as PC1 scores were positively correlated with more tropical species, such as skipjack tuna and common dolphinfish, but negatively correlated with more temperate species, such as swordfish and blue shark (Table 4). In contrast, variation in catch composition along PC2 primarily reflected an epipelagicmesopelagic axis as PC2 scores were positively correlated with epipelagic species, such as yellowfin tuna and wahoo, but negatively correlated with mesopelagic species, such as longnose lancetfish and snake mackerel (Table 4). Longline sets yielding slender or sharptail mola almost exclusively exhibited high PC1 values and a wide range of $\mathrm{PC} 2$ values, indicative of a generally tropical assemblage of variably epipelagic and mesopelagic composition. In contrast, longline sets yielding common mola exhibited high or low PC1 values in concert with a wide range of PC2 values, indicating a tropical (deep-set) or temperate (shallowset) assemblage of variably epipelagic and mesopelagic composition. The few longline sets yielding 2 mola species (slender/common, slender/sharptail, or sharptail/common) exhibited high PC1 values and a wide range of $\mathrm{PC} 2$ values, indicative of a tropical assemblage of epi- and mesopelagic species.

\section{DISCUSSION}

Common, slender, and sharptail mola exhibit spatiotemporal segregation within the eastern North Pacific in accordance with distinct thermal niches and seasonal movement patterns. Species distribution modeling and analysis of community composition informed by catches from the Hawaiian longline fishery revealed that, comparatively, the common mola is a more temperate species while slender and sharptail mola are more (sub)tropical species, consistent with previous studies on this family of enigmatic fishes (e.g. Gudger 1937, Pope et al. 2010, Horn et al. 2016, Nyegaard et al. 2018a). Fishery observer data also provided evidence of temporally segregated migrations of adult slender and sharptail mola to the region around the Hawaiian Islands that, in the context of previous studies on their eggs and/or larvae (Fitch 1950, Sherman 1961, Leis 1977), suggest these may constitute spawning migrations. Furthermore, catch probability of molid species seemingly changed with fishing gear type and across the $24 \mathrm{yr}$ of the study period, highlighting the effects of dynamic management and fisher behavior on bycatch in a pelagic longline fishery.

The spatiotemporal distribution of common mola in the eastern North Pacific reflects the broad range and cool thermal association of the species, and seasonal temperature cycles of the region. The presence of common mola from tropical to temperate waters of the open ocean matches global model predictions of suitable habitat for the genus occurring over a wide latitudinal range (Phillips et al. 2017). The common mola, which often spends the majority of its time in near-surface waters (Cartamil \& Lowe 2004, Dewar et al. 2010), exhibited an increased association with SSTs of $15-19^{\circ} \mathrm{C}$ (Fig. 3), matching results from other fisheries-dependent studies (Nakamura \& Sato 2014, Hahlbeck et al. 2017) as well as telemetry studies (e.g. Sims et al. 2009b, Potter et al. 2011, Sousa et al. 2016). The spatiotemporal pattern seen in both the deep- and shallow-set common mola models, i.e. of a more temperate distribution in the warming spring/ summer and more subtropical distribution during the cooling fall/winter (Figs. 2B,D \& 4A,B), is corroborated by similar findings from visual surveys in the northeast Atlantic (Sims \& Southall 2002, Houghton et al. 2006, Breen et al. 2017), satellite archival tagging from both sides of the North Atlantic (Sims et al. 2009b, Potter et al. 2011, Sousa et al. 2016) and North Pacific (Dewar et al. 2010, Thys et al. 2015), and global distribution modeling of the genus Mola (Phillips et al. 2017). Thus, seasonal shifts in latitudinal distribution during periods of regional warming or cooling enable common mola to occupy their specific thermal niche throughout most of the year (Sims et al. 2009b, Potter et al. 2011, Sousa et al. 2016). Furthermore, such seasonal north-south migrations, as 
are documented for common mola and myriad pelagic predators inhabiting the eastern North Pacific, may be initiated in response to changing temperature but are likely also driven in part by related changes in productivity and the availability of prey (Block et al. 2011).

The pattern of higher nominal CPUE and higher probability of capturing common mola in the shallowthan in the deep-set sector is likely at least partially attributable not only to temperature differences at the sea surface but also at depth, as it is consistent with diel and regional differences in the vertical movement patterns of the species as well as fishery operations in the different sectors. At nighttime, common mola remain in near-surface waters, whereas in the daytime, they typically undergo repeated movements from the surface to below the thermocline and back (e.g. Cartamil \& Lowe 2004, Sims et al. 2009b, Thys et al. 2015). Furthermore, common mola exhibit a comparatively shallower and narrower depth distribution in cooler, more temperate regions than in warmer, more tropical regions, likely as a result of behavioral thermoregulation (Dewar et al. 2010, Potter \& Howell 2011). The shallow-set sector operates during the nighttime (when common mola exhibit a narrower depth distribution) and at more northerly latitudes (where cooler temperatures at depth should promote a narrower depth distribution; Fig. 2C,D), thereby encountering common mola concentrated in a restricted depth range that enhances catchability. In contrast, the deep-set sector operates during the daytime (when common mola exhibit a wider depth distribution) and at more southerly latitudes (where warmer temperatures at depth should promote a wider depth distribution; Fig. 2E,F), thereby encountering common mola dispersed over a broad depth range that reduces catchability. This mirrors diel changes in the depth distribution of catchability for other species captured in Pacific longline fisheries (Ward \& Myers 2005) that exhibit distinct diel movement patterns (e.g. Abecassis et al. 2012, Arostegui et al. 2019b), as well as the more restricted descents and increased CPUE of pelagic fishes in regions where they experience vertical habitat compression (Prince \& Goodyear 2006, Stramma et al. 2012, Carlisle et al. 2017, Arostegui et al. 2019a). While past telemetry of common mola suggested that they may track vertically migrating prey and feed during the day and night (Sims et al. 2009a), more recent animal-borne data from the species revealed they only rarely feed at night (Nakamura et al. 2015). Thus, common mola catches in the shallow-set sector, which typically deploys fishing gear around dusk and retrieves it around dawn, may predominantly occur when these fish are active during crepuscular periods rather than in the middle of the night when they are less active, but the specific timing of capture is not resolved in these fishery data.

In direct contrast to the seasonal migration pattern of common mola in the eastern North Pacific, species distribution modeling revealed a potential spawning migration of slender mola northward across the equator in boreal fall/early winter and southward across the equator in boreal spring/early summer (Fig. 4D). The aggregation of slender mola around the Hawaiian Islands in late winter and early spring is consistent with previous studies in the area that found peak abundances of slender mola larvae at this time of year and identified it as the species' spawning season (Sherman 1961, Leis 1977). Furthermore, the average length of slender mola captured in the Hawaiian longline fishery matches that of adults of this species (Smith et al. 2010), and occasional catches of large numbers of slender mola on a single longline set are in accordance with previous findings of schooling behavior (Castro \& Ramos 2002, Smith et al. 2010, Horn et al. 2016). The boreal winter/ spring timing of this potential spawning aggregation around the Hawaiian Islands is paralleled by that of the Adriatic Sea, where peak abundance of adult slender mola and the presence of a sexually mature, pre-spawning individual have been documented in boreal winter, while post-spawning individuals have been documented in boreal spring (Jardas \& Knežević 1983, Dulčić et al. 2007). The wintertime northern limit of slender mola aggregation at $\sim 32^{\circ} \mathrm{N}$ in the eastern North Pacific (Fig. 4D) closely corresponds to the long-term average latitude $\left(30^{\circ}-32^{\circ} \mathrm{N}\right)$ of the subtropical convergence zone north of Hawai'i (Roden 1980, Dinniman \& Rienecker 1999). This is consistent with the distribution of slender mola larvae inside or south of a thermal front within the Sargasso Sea subtropical convergence zone at nearly the same latitude in the North Atlantic (Hellenbrecht et al. 2019). Furthermore, the region from $\sim 15^{\circ}-28^{\circ} \mathrm{N}$ and to the west of $150^{\circ} \mathrm{W}$, where slender mola catch is concentrated (Fig. 1D), consistently exhibits high eddy kinetic energy (Fig. S3) as the result of eddy generation in the lee of the islands and nearby seamounts (Royer 1978, Qiu \& Chen 2010, Liu et al. 2012). These mesoscale oceanographic features around Hawai'i, which experience a springtime peak in genesis (Lindo-Atichati et al. 2020) that matches the timing of the potential spawning aggregation, may entrain slender mola eggs and aid in the development and transport of the larvae (sensu Govoni et al. 2010, 
Mullaney \& Suthers 2013). The eddy dynamics of this region are also thought to yield a spawning hotspot for other pelagic fishes (Hyde et al. 2005) including the blue marlin Makaira nigricans, a tropical billfish that similarly associates with warm SSTs and undergoes trans-equatorial migrations to and from the Hawaiian Islands (albeit at opposite times of year as the slender mola; Carlisle et al. 2017). Although the slender mola achieves its northernmost distribution in the eastern North Pacific in boreal winter when temperatures above the thermocline are lowest (Fig. 2B,D), it is predominantly found in tropical and subtropical waters, consistent with the more tropical fish assemblage with which it is encountered (Shimose et al. 2010, 2013, this study; Fig. 6) as well as rare sightings of this species in temperate waters (e.g. Wheeler 1969, Eschmeyer et al. 1983).

Sharptail mola exhibited a (sub)tropical distribution more similar to that of slender mola but a temporally distinct range extension to the Hawaiian Islands more similar in its seasonal dynamics to the pattern found for common mola. The northward movement of sharptail mola in mid-spring to late summer (Fig. 4C) coincides with seasonal warming of the eastern North Pacific (Fig. 2B,D) and potentially also represents a spawning migration. The model prediction for sharptail mola to be found at more tropical latitudes during the boreal fall and winter, when seasonal cooling occurs in the study region, is consistent with the increased association of this species with warm waters (Seitz et al. 2002, this study; Fig. 3), cooccurrence with other tropical species (Gudger 1939, Fitch 1950, King 1951, Prakash et al. 2016, this study; Fig. 6), and rarity at temperate latitudes of both hemispheres (Houghton et al. 2006, Nyegaard et al. 2018a). Given the documented thermal segregation of sharptail mola from more temperate species of the genus Mola (Nyegaard et al. 2018a, this study), the northward range extension of sharptail mola in spring and summer during seasonal warming of the eastern North Pacific parallels seasonal migrations of common mola that enable them to track sea surface isotherms (Sims et al. 2009b, Potter et al. 2011, Sousa et al. 2016) and possibly respond to related spatiotemporal changes in foraging opportunity (sensu Block et al. 2011). The potential for this northward range extension to also represent a spawning migration is suggested by research cruises in Hawaiian waters in August and September of 1948 that found nearly 100 early life-stage Masturus lanceolatus in the stomachs of numerous yellowfin tuna (Fitch 1950). These $<1$ yr old fish (according to growth models by Liu et al. 2009) would have been hatched ear- lier in the season, possibly coinciding with the model-predicted summertime peak of adult sharptail mola in the area. Furthermore, there is evidence of segregated spawning activity by sharptail and slender mola in the Sargasso Sea (Hellenbrecht et al. 2019). Thus, the temporally disjoint presence of adult sharptail and slender mola near the Hawaiian Islands (this study, Fig. 4C,D), and of early developmental stages of the 2 species (Fitch 1950, Sherman 1961, Leis 1977), is suggestive of distinct spawning seasons, although research into adult reproductive status in the region is needed to confirm this possibility.

Fishing gear type affects molid catch probability in longline fisheries and represents an important consideration for conservation of these bycatch species. The notable decrease in catch probability of common mola in the shallow-set sector before versus after the emergency fishing closure in the early 2000 s is possibly due to gear type regulatory changes aimed at protecting endangered sea turtles. Interactions with sea turtles by shallow-set longliners resulted in the emergency closure of the sector from 2001-2004 before it was reopened with new regulations banning the use of both squid bait and J-hooks, and mandating the use of whole fish bait and circle hooks; these combined gear type regulatory changes were demonstrated to reduce sea turtle catch rates by $89 \%$ (Gilman et al. 2007). The effect of bait type on common mola catches is inconsistent among longline studies, as one documented a significantly higher catch rate with squid than mackerel bait (Coelho et al. 2012) while another found no significant difference in catch rate among those bait types (FernandezCarvalho et al. 2015). Similarly, studies from pelagic longline fisheries have documented either a significantly higher catch rate of common mola when using J- versus circle hooks (Fernandez-Carvalho et al. 2015) or no significant difference in catch rate among those hook types (Coelho et al. 2012, Domingo et al. 2012). Thus, while we could not isolate the effect of bait or hook type from year in any of our models due to collinearity, it seems probable that the combined regulatory changes, from squid to whole fish bait and $\mathrm{J}$ - to circle hooks, reduced the probability of common mola bycatch in the shallow-set sector from before to after the emergency closure (Fig. 5). Furthermore, a $\sim 27: 1$ catch ratio of common to sharptail mola in the shallow-set sector since its reopening suggests that any sharptail mola accidentally counted as common mola prior to the emergency closure (when they were potentially aggregated by observers) would have had negligible influence on the modeled, year-specific catch probabilities. In contrast, the trend of in- 
creasing catch probability of common mola in the shallow-set sector in the years since the emergency closure is possibly due to the observed eastward shift in effort along temperate latitudes into a region of persistently high habitat suitability (Fig. 2A,C; Phillips et al. 2017) that is closer to the California Current large marine ecosystem, a well-documented common mola hotspot (Thys et al. 2015, Hahlbeck et al. 2017). Although the deep-set sector shifted effort northeast during part of this same time period (Woodworth-Jefcoats et al. 2018), its effort distribution remained predominantly at tropical and subtropical latitudes where common mola catch likelihood is comparatively lower; this is consistent with our finding of no interannual trend in catch probability in the deep-set sector. The common mola is listed as Vulnerable with a decreasing population trend by the International Union for the Conservation of Nature (IUCN; Liu et al. 2015), which is of potential concern for the species in the eastern North Pacific due to its increasing number of interactions in the shallow-set sector of the Hawaiian longline fishery as well as its more than an order of magnitude higher bycatch rate in the California large-mesh drift gillnet fishery (Hahlbeck et al. 2017).

The primary limitation of this study is the uncertainty of our distribution models for the more rarely encountered species among those analyzed. Slender mola in the deep-set sector and common mola in the shallow-set sector were caught on 4.9 and $2.9 \%$ of longline sets, respectively, and their models exhibited greater explained deviance and AUC scores indicative of notable accuracy. In contrast, sharptail and common mola in the deep-set sector were caught on only 0.4 and $0.7 \%$ of longline sets, respectively, and their models exhibited lower explained deviance and AUC indicative of moderate accuracy with some unaccounted randomness in the species' distributions. The randomness in those models may be due to the sheer rarity of sharptail mola across the region and common mola outside of their preferred temperature range (only $0.1 \%$ of deep-set longlines occurred at SSTs $<19^{\circ} \mathrm{C}$ ). Alternatively or in addition, deep-set longline gear may be inefficient at sampling those species, which is likely given the dietary preferences of adult sharptail and common mola for gelatinous prey over the fish bait types used in the sector (Nakamura \& Sato 2014, Nakamura et al. 2015, Bakenhaster \& Knight-Gray 2016). Fisheries-dependent studies of other rarely encountered species have faced parallel issues and similarly yielded distribution models with low explained deviance but moderate predictive performance that provided valuable insight (e.g. Rooper et al. 2014, Barnett et al. 2017, Hazen et al. 2018). Even with its uncertainty, the deep-set common mola model yielded spatiotemporal patterns that were largely consistent with those of the higher quality shallow-set model for the same species; both identified higher catch likelihood in temperate waters and exhibited parallel seasonal shifts in the latitudinal threshold of that likelihood that were consistent with the species' documented behavior. The only difference among these Mola mola models was the presence of a secondary, tropical area of high (but comparatively lower) catch probability in the deep-set model that was not seen in the shallow-set model. This may be due to some molid species occupying a warmer niche being counted as M. mola in the tropical deep-set sector, namely Masturus lanceolatus prior to 2004 (when observers started enumerating the species separately) and $\mathrm{Mo}$ la alexandrini potentially throughout the study period (since it was recently redescribed taxonomically). Rebuilding the deep-set common mola model only with data from 2004-2018 (when sharptail mola were no longer potentially included) yielded similar spatiotemporal results (Fig. S4), suggesting the possibility that $M$. alexandrini is present in the region and driving the modeled pattern of elevated, tropical catch probability. Ultimately, our models for all species were highly consistent with the existing literature on their spatial segregation (e.g. Gudger 1937, Houghton et al. 2006, Nyegaard et al. 2018a), thermal associations (e.g. Seitz et al. 2002, Nakamura \& Sato 2014), spatiotemporal dynamics (e.g. Pope et al. 2010, Phillips et al. 2017), spawning seasons (e.g. Fitch 1950, Leis 1977), associated fish communities (e.g. King 1951, Shimose et al. 2010), and susceptibility to fishing gear (e.g. Coelho et al. 2012).

\section{CONCLUSION}

Our results demonstrated the spatiotemporal segregation of 3 molid species in the eastern North Pacific and identified potential underlying drivers of their separation. Paralleling their evolutionary relationships, there was greater similarity among the seasonal movement dynamics of common and sharptail mola (in sync with thermal cycles) than among either of these species and those of the slender mola (in sync with eddy genesis cycles). In addition, we discovered temporally segregated, potential spawning migrations of slender mola (from boreal fall to early winter) and sharptail mola (from mid-spring to late summer) to the region around the Hawaiian Islands. Fishery gear 
type and a shifting distribution of effort were found to have potential effects on molid catch probability; in particular, the increasing catch probability of common mola in the shallow-set sector is of potential concern given that this species is currently listed by the IUCN as Vulnerable, with a decreasing population trend (Liu et al. 2015). Additionally, comparison of our distribution models for common mola highlighted the possibility that the recently redescribed Mola alexandrini is being encountered and misidentified as its congener M. mola in the Hawaiian longline fishery. This study highlights the value of fishery observer programs, as the data they provide yield insight into the behavior and ecology of rare, understudied, and underappreciated species. Future work on molids should focus on identifying stock structure and additional aggregation sites of the various species, as well as clarifying the differences in distribution, behavior, and fishery interactions of M. mola and M. alexandrini in the North Pacific.

Data availability. The confidential fishery observer data used in this study are subject to NOAA order NAO 216-100: Protection of Confidential Fisheries Statistics and can only be disclosed under the conditions listed therein. The oceanographic data used in this study are publicly available from the EU Copernicus Marine Environment Monitoring Service (CMEMS, https://marine.copernicus.eu/) NOAA OISST (https://www.ncdc.noaa.gov/oisst), and NCEP GODAS (NOAA/OAR/ESRL PSL, Boulder, Colorado, https:// psl.noaa.gov/) online databases.

Acknowledgements. We thank Asuka Ishizaki for clarifying the regulatory history of the Hawaiian longline fishery, Stuart 'Joe' Arceneaux for insight into past and current observer protocols, Tim Essington for advice on distribution modeling of rarely encountered species, Grant Adams for advice on model validation, and Ryan Rykaczewski for reviewing the manuscript prior to submission. In particular, we thank the Pacific Islands Region Observer Program and the many fishers for making this study possible. This work was supported by NOAA project NA15OAR4320063 and NASA grant 80NSSC18K0757.

\section{LITERATURE CITED}

Abecassis M, Dewar H, Hawn D, Polovina J (2012) Modeling swordfish daytime vertical habitat in the North Pacific Ocean from pop-up archival tags. Mar Ecol Prog Ser 452: 219-236

Akaike H (1974) A new look at the statistical model identification. IEEE Trans Automat Contr 19:716-723

Arostegui M, Braun CD, Gaube P (2019a) Movement and thermal niche of the first satellite-tagged Mediterranean spearfish (Tetrapturus belone). Fish Oceanogr 28: 327-333

Arostegui M, Gaube P, Braun CD (2019b) Movement ecology and stenothermy of satellite-tagged shortbill spearfish (Tetrapturus angustirostris). Fish Res 215:21-26
Bakenhaster MD, Knight-Gray JS (2016) New diet data for Mola mola and Masturus lanceolatus (Tetraodontiformes: Molidae) off Florida's Atlantic coast with discussion of historical context. Bull Mar Sci 92:497-511

*Barnett LAK, Hennessey SM, Essington TE, Shelton AO, Feist BE, Branch TA, McClure MM (2017) Getting to the bottom of fishery interactions with living habitats: spatiotemporal trends in disturbance of corals and sponges on the US west coast. Mar Ecol Prog Ser 574:29-47

*Bass AL, Dewar H, Thys T, Streelman JT, Karl SA (2005) Evolutionary divergence among lineages of the ocean sunfish family, Molidae (Tetraodontiformes). Mar Biol 148:405-414

Behringer DW, Xue Y (2004) Evaluation of the global ocean data assimilation system at NCEP: the Pacific Ocean. In: Eighth Symposium on Integrated Observing and Assimilation Systems for Atmosphere, Oceans, and Land Surface. AMS $84^{\text {th }}$ Annual Meeting, Seattle, WA, p 11-15

Bigelow K, Musyl MK, Poisson F, Kleiber P (2006) Pelagic longline gear depth and shoaling. Fish Res 77:173-183

*Bock BA, Jonsen ID, Jorgensen SJ, Winship AJ and others (2011) Tracking apex marine predator movements in a dynamic ocean. Nature 475:86-90

Breen P, Cañadas A, Cadhla O, Mackey M and others (2017) New insights into ocean sunfish (Mola mola) abundance and seasonal distribution in the northeast Atlantic. Sci Rep 7:2025

*Bodziak J, Walsh WA (2013) Model selection and multimodel inference for standardizing catch rates of bycatch species: a case study of oceanic whitetip shark in the Hawaii-based longline fishery. Can J Fish Aquat Sci 70: 1723-1740

Carlisle AB, Kochevar RE, Arostegui MC, Ganong JE, Castleton M, Schratwieser J, Block BA (2017) Influence of temperature and oxygen on the distribution of blue marlin (Makaira nigricans) in the Central Pacific. Fish Oceanogr 26:34-48

Cartamil DP, Lowe CG (2004) Diel movement patterns of ocean sunfish Mola mola off southern California. Mar Ecol Prog Ser 266:245-253

* Castro JJ, Ramos AG (2002) The occurrence of Ranzania laevis off the Island of Gran Canaria, the Canary Islands, related to sea warming. J Fish Biol 60:271-273

Chang CT, Lin SJ, Chiang WC, Musyl MK and others (2020) Horizontal and vertical movement patterns of sunfish off eastern Taiwan. Deep Sea Res II 175:104683

* Coelho R, Santos MN, Amorim S (2012) Effects of hook and bait on targeted and bycatch fishes in an equatorial Atlantic pelagic longline fishery. Bull Mar Sci 88:449-467

Department of Commerce (2004) 50 CFR Parts 223, 224, and 660 - Fisheries off West Coast states and in the Western Pacific; highly migratory species fisheries; final rule. National Oceanic and Atmospheric Administration. Fed Regist 69:18443-18462

* Dewar H, Thys T, Teo SLH, Farwell C and others (2010) Satellite tracking the world's largest jelly predator, the ocean sunfish, Mola mola, in the Western Pacific. J Exp Mar Biol Ecol 393:32-42

Dinniman MS, Rienecker MM (1999) Frontogenesis in the North Pacific oceanic frontal zones - a numerical simulation. J Phys Oceanogr 29:537-559

* Domingo A, Pons M, Jiménez S, Miller P, Barceló C, Swimmer Y (2012) Circle hook performance in the Uruguayan pelagic longline fishery. Bull Mar Sci 88:499-511

*Dulčić J, Beg Paklar G, Grbec B, Morović M, Matić F, Lipej 
L (2007) On the occurrence of ocean sunfish Mola mola and slender sunfish Ranzania laevis in the Adriatic Sea. J Mar Biol Assoc UK 87:789-796

Eschmeyer WN, Herald ES, Hammann H (1983) A field guide to Pacific coast fishes of North America. Houghton Mifflin Company, Boston, MA

Fernandez-Carvalho J, Coelho R, Santos MN, Amorim S (2015) Effects of hook and bait in a tropical northeast Atlantic pelagic longline fishery: Part II - target, bycatch and discard fishes. Fish Res 164:312-321

Fitch JE (1950) Notes on some Pacific fishes. Calif Fish Game 36:65-73

Froese R, Pauly D (2019) FishBase. www.fishbase.org

* Gilman E, Kobayashi D, Swenarton T, Brothers N, Dalzell P, Kinan-Kelly I (2007) Reducing sea turtle interactions in the Hawaii-based longline swordfish fishery. Biol Conserv 139:19-28

KGilman E, Chaloupka M, Read A, Dalzell P, Holetschek J, Curtice C (2012) Hawaii longline tuna fishery temporal trends in standardized catch rates and length distributions and effects on pelagic and seamount ecosystems. Aquat Conserv 22:446-488

Govoni JJ, Hare JA, Davenport ED, Chen MH, Marancik KE (2010) Mesoscale, cyclonic eddies as larval fish habitat along the southeast United States shelf: a Lagrangian description of the zooplankton community. ICES J Mar Sci 67:403-411

* Gudger EW (1937) The natural history and geographical distribution of the pointed-tailed ocean sunfish (Masturus lanceolatus), with notes on the shape of the tail. Proc Zool Soc Lond A 107(Part 3):353-396

Gudger EW (1939) Three six-inch pointed-tailed ocean sunfish Masturus lanceolatus: the largest post-larvae on record. J Elisha Mitchell Sci Soc 55:305-313

*Hahlbeck N, Scales KL, Dewar H, Maxwell SM, Bograd SJ, Hazen EL (2017) Oceanographic determinants of ocean sunfish (Mola mola) and bluefin tuna (Thunnus orientalis) bycatch patterns in the California large mesh drift gillnet fishery. Fish Res 191:154-163

Hanley JA, McNeil BJ (1982) The meaning and use of the area under a receiver operating characteristic (ROC) curve. Radiology 143:29-36

Hazen EL, Scales KL, Maxwell SM, Briscoe DK and others (2018) A dynamic ocean management tool to reduce bycatch and support sustainable fisheries. Sci Adv 4: eaar3001

*He X, Bigelow KA, Boggs CH (1997) Cluster analysis of longline sets and fishing strategies within the Hawaiibased fishery. Fish Res 31:147-158

*Hellenbrecht LM, Freese M, Pohlmann JD, Westerberg $H$, Blancke T, Hanel R (2019) Larval distribution of the ocean sunfishes Ranzania laevis and Masturus lanceolatus (Tetraodontiformes: Molidae) in the Sargasso Sea subtropical convergence zone. J Plankton Res 41: 595-608

*Horn TS, Machado R, Weiss CV, Giora J, Malabarba LR (2016) Analysis of an astounding aggregation of Ranzania laevis (Molidae: Actinopterygii) in the tropical southwestern Atlantic. J Fish Biol 89:2212-2218

*Houghton JD, Doyle TK, Davenport J, Hays GC (2006) The ocean sunfish Mola mola: insights into distribution, abundance and behaviour in the Irish and Celtic Seas. J Mar Biol Assoc UK 86:1237-1243

Howell EA, Kobayashi DR, Parker DM, Balazs GH, Polovina JJ (2008) TurtleWatch: a tool to aid in the bycatch reduc- tion of loggerhead turtles Caretta caretta in the Hawaiibased pelagic longline fishery. Endang Species Res 5: $267-278$

Hutchins JB (2001) Molidae: molas (ocean sunfishes). In: Carpentier KE, Niem VH (eds) FAO species identification guide for fishery purposes. The living marine resources of the Western Central Pacific, Vol 6. Bony fishes, Part 4 (Labridae to Latimeriidae), estuarine crocodiles, sea turtles, sea snakes and marine mammals. Food and Agriculture Organization of the United Nations, Rome, p 3966-3968

*Hyde JR, Lynn E, Humphreys R Jr, Musyl M, West AP, Vetter R (2005) Shipboard identification of fish eggs and larvae by multiplex PCR, and description of fertilized eggs of blue marlin, shortbill spearfish, and wahoo. Mar Ecol Prog Ser 286:269-277

Jardas I, Knežević B (1983) A contribution to the knowledge of the Adriatic ichthyofauna-Ranzania laevis (Pennant, 1776) (Plectognathi, Molidae). Bilješke-Notes Inst Oceanogr Ribar Split 51:1-8

*Johnson GD, Britz R (2005) Leis' conundrum: homology of the clavus of the ocean sunfishes. 2. Ontogeny of the median fins and axial skeleton of Ranzania laevis (Teleostei, Tetraodontiformes, Molidae). J Morphol 266: $11-21$

Katayama E, Matsuura K (2016) Fine structures of scales of ocean sunfishes (Actinopterygii, Tetraodontiformes, Molidae): another morphological character supporting phylogenetic relationships of the molid genera. Bull Natl Mus Nat Sci Ser A Zool 42:95-98

King JE (1951) Two juvenile pointed-tailed ocean sunfish, Masturus lanceolatus, from Hawaiian waters. Pac Sci 5: 108-109

* Legendre P, Gallagher ED (2001) Ecologically meaningful transformations for ordination of species data. Oecologia 129:271-280

Leis M (1977) Development of the eggs and larvae of the slender mola, Ranzania laevis (Pisces, Molidae). Bull Mar Sci 27:448-466

KLindo-Atichati D, Jia Y, Wren J, Antoniades A, Kobayashi D (2020) Eddies in the Hawaiian archipelago region: formation, characterization, and potential implications on larval retention of reef fish. J Geophys Res Oceans 125: e2019JC015348

* Liu KM, Lee ML, Joung SJ, Chang YC (2009) Age and growth estimates of the sharptail mola, Masturus lanceolatus, in waters of eastern Taiwan. Fish Res 95:154-160

พ Liu Y, Dong C, Guan Y, Chen D, McWilliams J, Nencioli F (2012) Eddy analysis in the subtropical zonal band of the North Pacific Ocean. Deep Sea Res I 68:54-67

Liu J, Zapfe G, Shao KT, Leis JL and others (2015) Mola mola (errata version published in 2016). The IUCN Red List of Threatened Species 2015: e.T190422A97667070

Lyczkowski-Shultz J (2003) Preliminary guide to the identification of the early life history stages of molid fishes of the western central North Atlantic. NOAA Tech Memo NMFS-SEFSC-504

McGarigal K (2016) biostats: a collection of R functions written to aid in the statistical analysis of ecological data sets. www.umass.edu/landeco/teaching/ecodata/labs/ecodata _labs.html

Mullaney TJ, Suthers IM (2013) Entrainment and retention of the coastal larval fish assemblage by a short-lived, submesoscale, frontal eddy of the East Australian Current. Limnol Oceanogr 58:1546-1556 
Nakamura I, Sato K (2014) Ontogenetic shift in foraging habit of ocean sunfish Mola mola from dietary and behavioral studies. Mar Biol 161:1263-1273

Nakamura I, Goto Y, Sato K (2015) Ocean sunfish rewarm at the surface after deep excursions to forage for siphonophores. J Anim Ecol 84:590-603

NMFS (2010) Annual report on seabird interactions and mitigation efforts in the Hawaii longline fisheries for 2009. National Marine Fisheries Service, Pacific Islands Regional Office, Honolulu, HI

Nyegaard M, Loneragan N, Santos MB (2017) Squid predation by slender sunfish Ranzania laevis (Molidae). J Fish Biol 90:2480-2487

Nyegaard M, Loneragan N, Hall S, Andrew J, Sawai E, Nyegaard M (2018a) Giant jelly eaters on the line: species distribution and bycatch of three dominant sunfishes in the Southwest Pacific. Estuar Coast Shelf Sci 207:1-15

Nyegaard M, Sawai E, Gemmell N, Gillum J, Loneragan NR, Yamanoue Y, Stewart AL (2018b) Hiding in broad daylight: molecular and morphological data reveal a new ocean sunfish species (Tetraodontiformes: Molidae) that has eluded recognition. Zool J Linn Soc 182:631-658

Pan M, Walden J (2015) Measuring productivity in a shared stock fishery: a case study of the Hawaii longline fishery. Mar Policy 62:302-308

* Phillips ND, Harrod C, Gates AR, Thys TM, Houghton JD (2015) Seeking the sun in deep, dark places: mesopelagic sightings of ocean sunfishes (Molidae). J Fish Biol 87: 1118-1126

Phillips ND, Reid N, Thys T, Harrod C and others (2017) Applying species distribution modelling to a data poor, pelagic fish complex: the ocean sunfishes. J Biogeogr 44: 2176-2187

* Polovina JJ, Woodworth-Jefcoats PA (2013) Fishery-induced changes in the subtropical Pacific pelagic ecosystem size structure: observations and theory. PLOS ONE 8:e62341

Polovina JJ, Abecassis M, Howell EA, Woodworth P (2009) Increases in the relative abundance of mid-trophic level fishes concurrent with declines in apex predators in the subtropical North Pacific, 1996-2006. Fish Bull 107: 523-531

* Pope EC, Hays GC, Thys TM, Doyle TK and others (2010) The biology and ecology of the ocean sunfish Mola mola: a review of current knowledge and future research perspectives. Rev Fish Biol Fish 20:471-487

Potter IF, Howell WH (2011) Vertical movement and behavior of the ocean sunfish, Mola mola, in the northwest Atlantic. J Exp Mar Biol Ecol 396:138-146

Potter IF, Galuardi B, Howell WH (2011) Horizontal movement of ocean sunfish, Mola mola, in the northwest Atlantic. Mar Biol 158:531-540

* Prakash S, Ajith Kumar TT, Thangaraj M (2016) DNA Barcoding of sharp tail sunfish Masturus lanceolatus Lienard, 1840 (Tetraodontiformes: Molidae). Proc Zool Soc (Calcutta) 69:153-156

* Prince ED, Goodyear CP (2006) Hypoxia-based habitat compression of tropical pelagic fishes. Fish Oceanogr 15: 451-464

Qiu B, Chen S (2010) Interannual variability of the North Pacific Subtropical Countercurrent and its associated mesoscale eddy field. J Phys Oceanogr 40:213-225

R Core Team (2019) R: a language and environment for statistical computing. Version 3.6.1. R Foundation for Statistical Computing, Vienna

Reynolds RW, Banzon VF, NOAA CDR Program (2008)
NOAA optimum interpolation 1/4 degree daily sea surface temperature (OISST) Analysis, Version 2. Tech Rep. NOAA National Centers for Environmental Information

Roden G (1980) On the subtropical frontal zone north of Hawaii during winter. J Phys Oceanogr 10:342-362

* Rooper CN, Zimmermann M, Prescott MM, Hermann AJ (2014) Predictive models of coral and sponge distribution, abundance and diversity in bottom trawl surveys of the Aleutian Islands, Alaska. Mar Ecol Prog Ser 503: 157-176

Royer TC (1978) Ocean eddies generated by seamounts in the North Pacific. Science 199:1063-1064

Sagara K, Ozawa T (2002) Report on the questionnaires about molids in Japan. Bull Jpn Soc Fish Oceanogr 66:164-167

* Santini F, Tyler JC (2002) Phylogeny of the ocean sunfishes (Molidae, Tetraodontiformes), a highly derived group of teleost fishes. Ital J Zool 69:37-43

Sawai E, Yamanoue Y, Yoshita Y, Sakai Y, Hashimoto H (2011) Seasonal occurrence patterns of Mola sunfishes (Mola spp. A and B; Molidae) in waters off the Sanriku region, eastern Japan. Jpn J Ichthyol 58:181-187

* Sawai E, Yamanoue Y, Nyegaard M, Sakai Y (2018) Redescription of the bump-head sunfish Mola alexandrini (Ranzani 1839), senior synonym of Mola ramsayi (Giglioli 1883), with designation of a neotype for Mola mola (Linnaeus 1758) (Tetraodontiformes: Molidae). Ichthyol Res 65:142-160

* Seitz AC, Weng KC, Boustany AM, Block BA (2002) Behaviour of a sharptail mola in the Gulf of Mexico. J Fish Biol 60:1597-1602

* Sherman K (1961) Occurrence of early developmental stages of the oblong ocean sunfish Ranzania laevis (Pennant) in the central North Pacific. Copeia 1961:467-470

Shimose T, Yokawa K, Saito H (2010) Habitat and food partitioning of billfishes (Xiphioidei). J Fish Biol 76:2418-2433

* Shimose T, Yokawa K, Tachihara K (2013) Occurrence of slender mola Ranzania laevis (Pennant, 1776) in stomachs of blue marlin Makaira nigricans Lacépède, 1802. J Appl Ichthyol 29:1160-1162

* Silvani L, Gazo M, Aguilar A (1999) Spanish driftnet fishing and incidental catches in the western Mediterranean. Biol Conserv 90:79-85

* Sims DW, Southall EJ (2002) Occurrence of ocean sunfish, Mola mola near fronts in the western English Channel. J Mar Biol Assoc UK 82:927-928

* Sims DW, Queiroz N, Doyle TK, Houghton JD, Hays GC (2009a) Satellite tracking of the world's largest bony fish, the ocean sunfish (Mola mola L.) in the North East Atlantic. J Exp Mar Biol Ecol 370:127-133

* Sims DW, Queiroz N, Humphries NE, Lima FP, Hays GC (2009b) Long-term GPS tracking of ocean sunfish Mola mola offers a new direction in fish monitoring. PLOS ONE 4:e7351

Smith KA, Hammond M, Close PG (2010) Aggregation and stranding of elongate sunfish (Ranzania laevis) (Pisces: Molidae) (Pennant, 1776) on the southern coast of Western Australia. J R Soc West Aust 93:181-188

* Sousa LL, Queiroz N, Mucientes G, Humphries NE, Sims DW (2016) Environmental influence on the seasonal movements of satellite-tracked ocean sunfish Mola mola in the north-east Atlantic. Anim Biotelem 4:7

Stramma L, Prince ED, Schmidtko S, Luo J and others (2012) Expansion of oxygen minimum zones may reduce available habitat for tropical pelagic fishes. Nat Clim Chang 2:33-37 
Swets JA (1988) Measuring the accuracy of diagnostic systems. Science 240:1285-1293

Thys TM, Whitney J, Hearn A, Weng KC and others (2013) First record of the southern ocean sunfish, Mola ramsayi, in the Galápagos Marine Reserve. Mar Biodivers Rec 6: e70

Thys TM, Ryan JP, Dewar H, Perle CR and others (2015) Ecology of the ocean sunfish, Mola mola, in the southern California Current system. J Exp Mar Biol Ecol 471:64-76

Thys TM, Hearn AR, Weng KC, Ryan JC, PeñaherreraPalma C (2017) Satellite tracking and site fidelity of short ocean sunfish, Mola ramsayi, in the Galapagos Islands. J Mar Sci 2017:7097965

Wagenmakers EJ, Farrell S (2004) AIC model selection using Akaike weights. Psychon Bull Rev 11:192-196

Walker HJ Jr, Hastings PA, Hyde JR, Lea RN, Snodgrass OE, Bellquist LF (2020) Unusual occurrences of fishes in the Southern California Current System during the warm water period of 2014-2018. Estuar Coast Shelf Sci 236: 106634

Walsh WA, Brodziak J (2015) Billfish CPUE standardization in the Hawaii longline fishery: model selection and multimodel inference. Fish Res 166:151-162

Walsh WA, Kleiber P (2001) Generalized additive model and regression tree analyses of blue shark (Prionace glauca) catch rates by the Hawaii-based commercial longline fishery. Fish Res 53:115-131

Walsh WA, Ito RY, Kawamoto KE, McCracken M (2005) Analysis of logbook accuracy for blue marlin (Makaira nigricans) in the Hawaii-based longline fishery with a generalized additive model and commercial sales data. Fish Res 75:175-192

Editorial responsibility: Elliott Hazen,

Pacific Grove, California, USA

Reviewed by: M. Nyegaard and 2 anonymous referees
Walsh WA, Bigelow KA, Sender KL (2009) Decreases in shark catches and mortality in the Hawaii-based longline fishery as documented by fishery observers. Mar Coast Fish 1:270-282

*Ward P, Myers RA (2005) Inferring the depth distribution of catchability for pelagic fishes and correcting for variations in the depth of longline fishing gear. Can J Fish Aquat Sci 62:1130-1142

Wheeler A (1969) The fishes of the British Isles and North West Europe. Macmillan, London

Wood S (2019) mgcv: mixed GAM computation vehicle with automatic smoothness estimation. Version 1.8-29. https:// cran.r-project.org/web/packages/mgcv/index.html

Woodworth-Jefcoats PA, Polovina J, Drazen J (2018) Synergy among oceanographic variability, fishery expansion, and longline catch composition in the central North Pacific Ocean. Fish Bull 116:228-239

* Yamanoue Y, Miya M, Matsuura K, Katoh M, Sakai H, Nishida M (2004) Mitochondrial genomes and phylogeny of the ocean sunfishes (Tetraodontiformes: Molidae). Ichthyol Res 51:269-273

* Yamanoue Y, Miya M, Matsuura K, Katoh M, Sakai H, Nishida M (2008) A new perspective on phylogeny and evolution of tetraodontiform fishes (Pisces: Acanthopterygii) based on whole mitochondrial genome sequences: basal ecological diversification? BMC Evol Biol 8:212

* Yoshita Y, Yamanoue Y, Sagara K, Nishibori M and others (2009) Phylogenetic relationship of two Mola sunfishes (Tetraodontiformes: Molidae) occurring around the coast of Japan, with notes on their geographical distribution and morphological characteristics. Ichthyol Res 56: 232-244

Submitted: June 23, 2020

Accepted: September 28, 2020

Proofs received from author(s): November 6, 2020 